\title{
Bobler over av global helse
}

\author{
Hans Rosling er oppdagelsesreisende i internasjonal helse. Ved hjelp av sin boblegraf har han \\ funnet verdenshelsens hvite flekker. Han har oppdaget sannheten om Afrika, Asia, de arabiske \\ landene og Latin-Amerika. Oppdelingen i u-land og i-land er en stor bløff, mener han.
}

Det er på høy tid med et globalt, bevegelig og kunnskapsbasert helsekart. Hans Rosling har tatt på seg oppgaven og viser sin statistikk som en meteorolog presenterer værmeldingen - bare mer underholdende.

Av og til mye mer underholdende. Det skjer at han avslutter sitt bejublede statistikkshow med å ta av seg skjorten, bøye nakken bakover og stikke en bajonett ned i halsen. Meget langt ned. - Gastroskopien ble utviklet i tyske Freiburg da en kirurg møtte en sverdsluker, påstår han, men ser rimelig lur ut.

Hans Rosling er professor i internasjonal helse ved Karolinska Institutet i Stockholm, flerfoldig prisbelønnet forsker og en innovativ entreprenør. Han er også, tross sine 61 år, et naturtalent når det gjelder skøyeraktig oppførsel. Nå reiser han rundt og viser verdens sanne ansikt ved hjelp av bevegelig statistikk med runde fargerike bobler. Søyledreperen fra Uppsala holder forestillinger for både monarker og ministre.

\section{Viser verden}

Kjendiseriet er basert på noe vi kan kalle en boblegraf, en nyvinning i presentasjonsteknikk som gjør de globale effektene av nasjonale helsetall meget oversiktlige. For statistikk er den internasjonale helsens kjerne.

- Helse er så mye mer enn bare summen av friske individer. Tallene beskriver hvordan samfunnet fungerer sosialt, økonomisk og miljømessig, sier Hans Rosling. Ved hjelp av sine bobler visualiserer han verdens økonomiske utvikling så enkelt at til og med $\mathrm{Al}$ Gore stormet scenen etter en forelesning og entusiastisk utbrøt «I didn't know that, I did not have the slightest idea!» Slikt er både morsomt og urovekkende, for hvis Al Gore, som selv har reist verden rundt og fylt auditoriene med globale fakta, ikke har hatt den «ringeste anelse» om hvordan verden ser ut hva da med alle professorer, næringslivsledere og politikere?

- Mange beslutninger i vest bygger på foreldede forestillinger om resten av verden, konstaterer Rosling, og ser strålende fornøyd ut, for det er alltid positivt med en diagnose som gir håp om bedring.

\section{Interaktiv professor}

200 fargelagte sirkler danser mellom Xog Y-aksene. Hver «boble» symboliserer et land, og plasseringen i diagrammet beskriver landets statistiske ståsted et spesifikt år. Da aha-opplevelsen ligger i selve bevegelsen, kan det være klokt å kikke nærmere på prinsippet før man leser videre. Artikkelen vil derfor ta en liten pause, slik at leseren kan gå til sin PC og klikke seg inn på nettstedet $w w w$. gapminder.org eller se professoren i aksjon på YouTube. Det er nemlig på Internett Hans Rosling har hatt sitt største gjennombrudd. På youtube.com ligger over 300 klipp fra forelesninger verden rundt, og slike presentasjonsfilmer er blitt viktigere enn noe annet Hans Rosling har publisert gjennom hele sitt yrkesliv - inklusive avhandlinger, forskning, bøker og forelesninger. Det er store ord, men de er hans egne: - Via Internett når budskapet ut til millioner av mennesker. Det gjør ikke en gang den mest velformulerte forskningsrapport, sier han.

$$
\text { (Pause) }
$$

\section{Provoserer og forfører}

Hans Roslings utfordring ligger i ikke å la den fargerike innpakningen overskygge innholdet. Hovedpoenget er at dagens verden ikke lenger er oppdelt i utviklingsland og industriland, noe vanlige søylestatistikere er lurt til å tro. - Begrepene u-land og i-land brukes over en lav sko innen internasjonal helse, politikk og bistand selv om vi mangler en fornuftig definisjon, sier Rosling.

Han både provoserer og forfører ved hjelp av sine pinlig enkle bobler. Pinlig, fordi de avslører den vestlige elitens livsløgn som allvitere og viser vår nakne avhengighet av enkle forklaringsmodeller. Hans Rosling vifter med tryllestaven og konverterer noen statistiske tidsserier til svevende fargeklatter. U-landet Iran havner forbausende nær vårt eget hjørne.

- Iran er ikke et utviklingsland når det gjelder helse. Gjennomsnittsalderen er 70 år og familiene har to barn. Sykehusene utfører nyretransplantasjoner og hjerteklaffoperasjoner med høy kvalitet og presisjon, sier han. - Iran er som et Italia 1970 med Mussolini ved makten, men det gir oss ikke rett til å klumpe landet sammen med Afghanistan, noe som ofte gjøres.

\section{Samme reiserute}

I løpet av etterkrigstiden har mange såkalte u-land nådd diagrammets velstandsdel. I postindustrielle høyinnkomstland utgjør redusert dødelighet en stadig dårligere målestokk. Barnedødeligheten ligger på tre per 1000 barn.

- Alle land gjør samme reise mot velstand, men i forskjellig tempo. De vi kaller u-land er derfor ikke en samlet gruppe med like behov, sier Hans Rosling. Hovedparten av verdens befolkning lever slik vi selv har gjort gjennom hele 1900-tallet, med relativt mye såpe og varm mat. To milliarder lever slik vi gjorde på 1800-tallet, og en halv milliard har livsvilkår à la vårt 1700 -tall. Kun noen få u-bobler befinner seg i total slum.

En moderne global helseindeks må derfor ta hensyn til minst fire landgrupper, mener Rosling. Det er høyinnkomstland med galopperende Alzheimers sykdom og osteoporose; land med lavere innkomst som domineres av kroniske sykdommer, ulykker og mentale helseproblemer; lavinnkomstland med infeksjoner og undernæring; og kollapsede land med krig, nød og armod.

- Der finner vi noen få land som knapt har begynt sin velstandsreise, for eksempel Afghanistan, Kongo og Darfu-provinsen i Sudan.

\section{Fordommer og rasisme}

Vi setter oss ned så Hans Rosling får trukket pusten før han kaster seg inn i neste resonnement. Som statistikkens Indiana Jones hugger han seg gjennom en forstokket urskog av gamle holdninger. Den tid er forbi da verdens helsetilstand korrelerte med klima og kultur.

- Vårt problem er ikke ukunnskap men forutinntatte meninger. Derfra er veien ikke lang til mer eller mindre bevisst rasisme, sier han. Blikket er blitt alvorlig. - Vi snakker om «oss selv» og «de andre» som om det fantes to forskjellige slags livssituasjoner i verden. Vi er fulle av kulturelle og innebygde fordommer og plasserer gjerne land, folk og kulturer utenfor den anglosaksiske sfæren for seg selv. Forståelsen av internasjonal helse blir dermed et offer for forenklinger og myter.

- Mange rike land bygger dessverre sin helsemessige og økonomiske utvikling på 


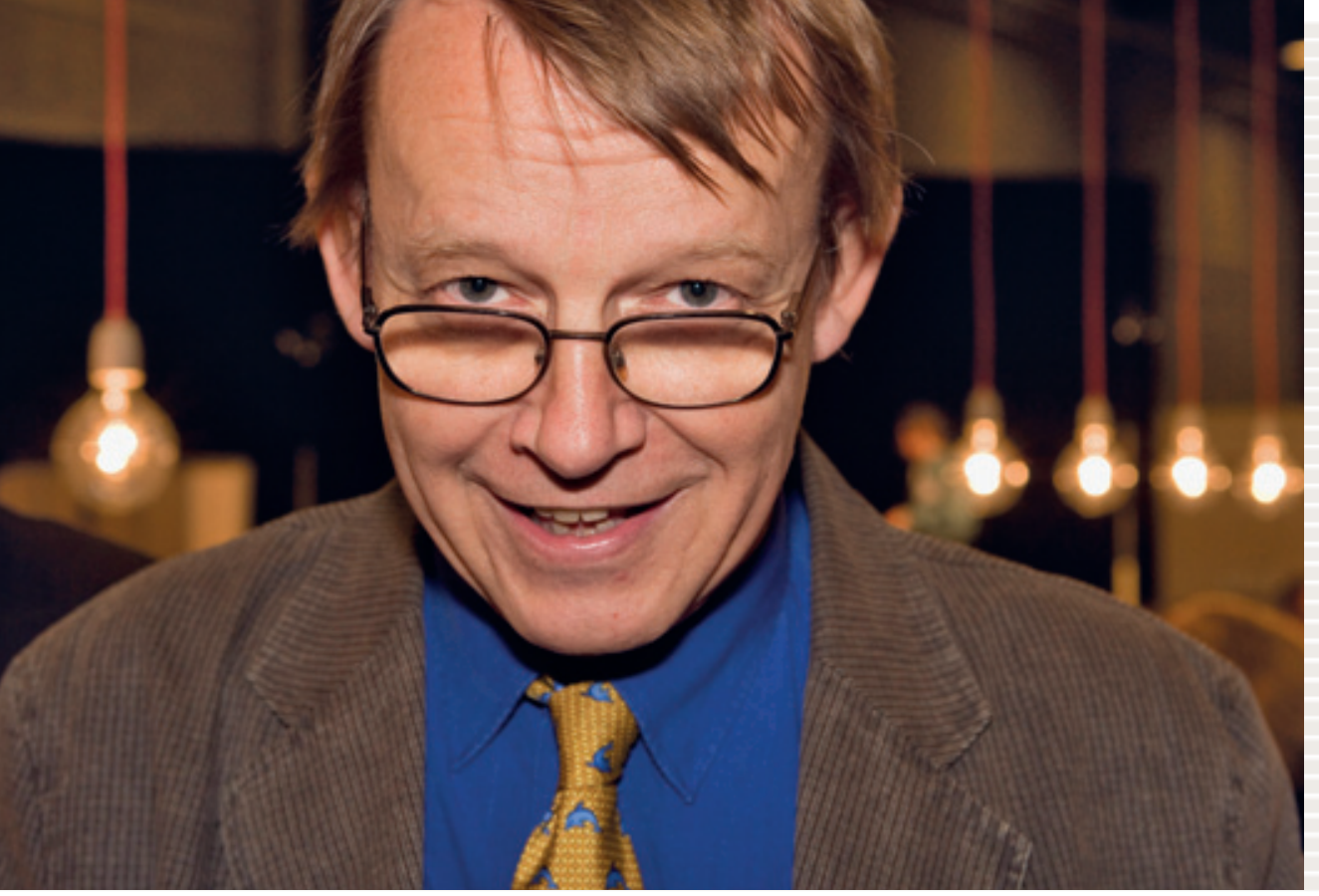

et verdensbilde med tydelige fordomsfulle røtter i 1800-tallet. Det er mest lettvint slik.

\section{En skrekkelig opplevelse}

Hans Roslings boblegraf bygger på programvaren Trendalyzer som er utviklet av sønnen Ola Rosling og hans kone Anna Rönnlund. Sammen dannet de Stiftelsen Gapminder, med navnet fra T-banedørene i London («Mind the gap») og støtte fra det statlige svenske bistandsorganet Sida.

Listen over applauderende statsledere og velkjente bedriftsledere er imponerende.

Rosling har vist sine boblegrafer i både FN, utenriksdepartementer, for kronprins Haakon Magnus og i finanskretser.

- Næringslivet er veldig interessert. Uten rett kunnskap om de faktiske forhold er det vanskelig å investere, sier han. I de politiske og akademiske korridorene går det tregere. - Det var en skrekkelig opplevelse å oppdage at finansvalpene besitter større faktakunnskap om verden enn universitetene, professorene og deres studenter, forteller han. - Ikke en gang vår bistand er alltid basert på adekvate fakta. Bistandsorganisasjonene kjører sin politikk med grove grep uten hensyn til kulturelle detaljer.

\section{Leger løfter blikket}

Land og verdensdeler har stor intern spredning på helse og økonomi, og det blir vanskelig med kun én medisinsk policy. Store innkomstforskjeller gir helt ulike muligheter til medisinering. I noen afrikanske land er mer enn $20 \%$ t av de voksne hivsmittet, mens andre land har mindre enn $1 \%$ smittede.

- Allikevel får vi høre at «så lenge u-landet Brasil kan ordne frem hivmedisiner, så kan vel også afrikanske land gjøre det». Men hallo? Brasil er ti ganger rikere enn Zambia, som har 20 ganger større andel hivinfiserte, sier en oppgitt Hans Rosling.

Kritikken om forutinntatt ignoranse rammer også hans egen yrkesgruppe.
- Også legestanden i våre høyinnkomstland har stor kunnskapsbrist i verdens helsesituasjon. Norske leger er selvsagt ikke noe unntak, hevder Rosling. Han mener at legeyrket i dag er så spesialistfokusert at legen til slutt kan bli sittende med skylapper mot omverdenen. Generelt burde legeutdanningen inneholde mye mer kunnskap om hvordan helsen varierer i verden. Som lege får man bruk for slik kunnskap i helt uventede situasjoner. Dagens pasienter reiser over hele jordkloden. - Thailand har god sykepleie. Hvis diabetespasienten ringer fra Tanzania, har du et problem.

\section{Afrikansk bakgrunn}

Hans Rosling har ikke minst viet sitt yrkesliv til arbeid og forskning rundt fattigdom og helse i Afrika. Et par år med «vanlig» legearbeid i Mosambik - meget langt fra skandinavisk normalitet - ble etterfulgt av over 20 år med årlige feltstudier.

Med glimtet tilbake i øyet konstaterer han at medisinske problemer i fattige land gjerne har sitt opphav i årsaker som ikke en gang en vestlig universitetsutdanning kan råde bot på. - Det er lett å komme dit og mene at folk «burde forstå» at vann må kokes så barna ikke får diaré. Men når man undersøker hvor mye ved som må til, innser man at koking av vann blir økonomisk umulig for veldig mange, sier han. - Som sykehuslege levde jeg i en illusjon, konkluderer han.

En periode var Hans Rosling ansvarlig for helse- og sykepleien i Nacal-distriktet, et område med 360000 innbyggere. Regionens medisinske kompetanse besto av ham selv og en legekollega. Etter et dramatisk epidemisk utbrudd av spastisk paralyse fant han at årsaken var hydrogencyanid (blåsyre), som kom fra kassavaroten. På grunn av tørke og hungersnød spiste mange roten uten å ta hensyn til de tradisjonelle avgiftende tillagingsmetodene. Den gang sam-

\section{Hans Rosling}

Født 27. juli 1948 i Uppsala

- Gjestestudent i India 1972

- Distriktslege i Mosambik, navngir sykdommen konzo 1981

- Forsket rundt internasjonal helse og fattigdom 1980-2000

- Mottok Svenska Läkaresällskapets jubileumspris 2007

- Professor i internasjonal helse ved Karolinska Institutet

Foto www.barnplantorna.se

arbeidet Hans Rosling med legestudenten Thorkild Tylleskär, nå professor ved Senter for internasjonal helse (CIH) ved Universitetet i Bergen. Sammen ga de sykdommen betegnelsen «konzo», etter lokalbefolkningens ord for «sammenbundne knær». I dag er konzo et epidemiologisk begrep.

\section{Uhelbredelig optimist}

Hans Roslings engasjement lider derimot ikke av paralyse. Han er en uhelbredelig optimist og blir helt andpusten av vise at jordkloden hele tiden blir en bedre plass å vokse opp på for stadig flere av oss.

Påstanden om at befolkningseksplosjonen forårsaker klimaproblemet tilbakeviser han med kraft. - Det er uhederlig å laste klimaet over på de fattige. Tross sin fattigdom er for eksempel både Bangladesh og Indonesia nede i to barn per kvinne, som de fleste land, sier han.

- Uten tilgang til begripelig statistikk undervurderer vi verdens utvikling. Så enkelt er det. I april ble det klart at Verdensbanken åpner sine databaser for helt fri bruk takket være Hans Roslings utrøttelige lobbyarbeid (http://data.worldbank.org).

- Hvordan blir man sverdsluker?

- Man lærer av en som kan. Jeg fikk Sveriges største sverdsluker Hjalmar Wickman som pasient og kunne ikke la være å stille samme spørsmål, forteller han. Dette var etter at Rosling selv hadde forsøkt med en ventrikkelsonde over den tynne delen av en fiskestang. Det gikk dårlig. Wickman utbrast indignert: «Men leser De ikke anatomi? Matstrupen er jo et flatt organ!»

- Det går bedre med en bajonett fra 1815 . Man trekker nakken bakover og fører ned en flat lang gjenstand. Men prøv ikke dette hjemme alene, advarer Hans Rosling.

\section{Morten Valestrand}

morten.valestrand@swipnet.se Göteborg 